PIOTR MAGIER

Forum Pedagogiczne

$2016 / 2$ cz. 1

Instytut Pedagogiki

Wpłynęło: 16.03 .2016

Katolicki Uniwersytet Lubelski Jana Pawła II

Lublin

Zatwierdzono do druku: 24.05.2016

DOI: $10.21697 / \mathrm{fp} .2016 .2 .10$

\title{
O POTRZEBIE ETYKI W PEDAGOGICE
}

Streszczenie: Przedmiotem artykułu jest relacja między pedagogiką a etyką. Artykuł ma charakter analityczny oraz metateoretyczny. Celem artykułu jest uzasadnienie tezy o potrzebie systemowej obecności etyki w pedagogice. Zdaniem autora jej brak prowadzi do degeneracji pedagogiki jako nauki w jej aspekcie (poziomie) normatywnym. Sformułowaną tezę autor uznaje za istotną w kontekście dyskusji dotyczących naukowego statusu pedagogiki, zwłaszcza jej humanistycznej specyfiki oraz upowszechniania się naturalistycznego paradygmatu nauki.

Słowa kluczowe: etyka, pedagogika, normatywność, polska tradycja uprawiania pedagogiki, cele, język, metody badawcze pedagogiki, naturalizm.

Zainteresowanie relacją między wychowaniem a moralnością nie jest nowe. Na terenie nauki posiada ono długie i nasycone bogatą treścią dzieje. Także współcześnie dla wielu teoretyków i praktyków oczywista jest potrzeba obecności moralności w wychowaniu oraz etyki w pedagogice (Szczęsny 2003). Powyższa oczywistość skłaniać może do wątpliwości dotyczącej zasadności ponownego zajmowania się tą problematyką. Uzasadnione wydają się pytania dotyczące możliwości opisu nowych, nieznanych dotychczas zależności w badanym zakresie: pytania o to, czy wypowiedzi dotyczące związku etyki i pedagogiki, wychowania i molarności wprowadzają nową wiedzę, czy są jedynie powtórzeniami znanych już twierdzeń. Niemniej funkcjonują także opinie, iż pewne aspekty związku pedagogiki i etyki (np. teoria sprawności moralnych) pozostają nadal marginalizowane (de Tchorzewski 2013) lub że obecność etyki w pedagogice (humanistyce) jest niewystarczająca: „kiepska”, „zła” (Witkowski 2007, s. 26-28).

W tekście odróżniam dwa poziomy: dyscyplinarny oraz przedmiotowy (zjawiskowy), a w konsekwencji odróżniam etykę od moralności oraz pedagogikę od wychowania (Homplewicz 1996). Za podstawowy uznaję poziom dyscyplinarny zamierzam zająć się relacją między pedagogiką a etyką, traktując odniesienia przedmiotowe jako kontekst, a także inspirację do podjętych analiz. W związku z tym, że skupiam się na poziomie metateorii (!), w większości pomijam szeroką 
dyskusję o znaczeniu moralności dla wychowania (edukacji) - zarówno w aspekcie praktyki (nie rozwiązuję problemów praktycznych), jak i teorii (nie analizuję, czy tym bardziej nie postuluję, określonej koncepcji etycznej) - wykorzystując jedynie niektóre wątki wspomnianej dyskusji.

Podstawowa teza tekstu wyraża przekonanie, iż odrzucenie treści etycznych (oraz szerzej aksjologicznych) w pedagogice prowadzi do degeneracji pedagogiki, utraty jej teoretycznej i metodologicznej tożsamości ${ }^{1}$. Mimo że sama teza nie jest zapewne oryginalna, stały proces zmiany (rozwoju) pedagogiki, warunkowany po części współczesną, niestabilną sytuacją mentalną świata Zachodu, kreuje nowe okoliczności zasługujące w moim przekonaniu na stałą, krytyczną uwagę (Szewczak 2013). Ponadto przyjmuję, że analiza przedmiotowej relacji traktowana być może jako przykład (wprowadzenie) szerszych problemów dotyczących pedagogiki (jako nauki). Chodzi mianowicie o relację pedagogiki względem podstawowych dla niej nauk filozoficznych (w tym normatywnych), jak np. antropologia filozoficzna (Szczęsny 2003), a ostatecznie o funkcje i miejsce treści normatywnych w strukturze wiedzy pedagogicznej.

Pisząc o konieczności obecności etyki w pedagogice, analogicznie do propozycji Andrzeja Bronka, odróżniam dwie jej postacie: obecność systemową oraz różne formy obecności niesystemowej. Przez określenie „obecność systemowa” rozumiem włączanie w dorobek jednej nauki (pedagogiki) osiągnięć, problemów bądź strategii badawczych typowych dla innej nauki (etyki), w funkcjach (aspektach) heurystycznej oraz uzasadniającej. Mówiąc o „obecności niesystemowej”, mam na myśli okoliczności, kiedy jedna dziedzina wiedzy (etyka) inspiruje badaczy reprezentujących inną dziedzinę (pedagogikę) do specyficznego podejścia metodologicznego, przyjęcia określonej postawy względem prowadzonych badań, podejmowania specyficznych wyzwań badawczych w ramach kontekstu odkrycia (Bronk 2005). Ponadto chodzi także o formowanie (przyjęcie) określonej postawy moralnej, ważnej dla sposobu (jakości) uprawiania nauki (Majdański 2009; Michalik-Surówka 2003; Witkowski 2007; Ostrowska 2007). Mimo że obie sytuacje są istotne dla nauki i jej rozwoju, w tekście eksploatuję pierwszy ze wskazanych wątków, a więc chodzi mi o systemową obecność etyki w pedagogice.

Prezentowana wypowiedź ma charakter analityczny i aspektowy. Uznaję ją za zbiór elementarnych uwag o przedmiocie interesującej mnie relacji, uzasadniających wyżej sformułowaną główną tezę tekstu, uwag nie tylko opisowych, lecz

1 „Wyodrębnienie pedagogiki w osobną naukę i to w chwili, kiedy intelektualizm moralny zaczął szerzyć swe wpływy, było fatalnym zarówno dla etyki, jak i dla samej pedagogiki. Pierwszej odbierało najważniejszy jej rozdział i pozbawiało ją tych zagadnień, które są probierzem prawdziwej wartości moralnej, oderwanych teorii etycznych. Drugą odrywało od jej macierzystego pnia i pozostawiało bez silnych analitycznych podstaw naukowych z dziedziny etyki. Jednocześnie rzucało ją ono na pastwę wpływów intelektualistycznych i podporządkowywało coraz bardziej dydaktyce i metodom psychologii doświadczalnej” (Woroniecki 1995, s. 23). 
także wartościujących. Zatem prezentowana wypowiedź traktowana być może jako wyraz zaniepokojenia zmianami, jakim (w pewnym zakresie) podlega pedagogika. Mam jednak nadzieję, że niniejszy tekst nie jest wyłącznie przykładem niewybrednego utyskiwania, lecz zmierza ku określeniu istotnych problemów w badanym zakresie. Prezentowanej wypowiedzi przypisuję zatem nie tylko cele poznawcze, lecz także praktyczne, oceniam bowiem zmiany, którym podlega macierzysta dla mnie dyscyplina.

Tekst opracowany został na podstawie literatury polskojęzycznej i w związku z tym formułowane uwagi odnoszę zasadniczo do sytuacji pedagogiki w Polsce. Niemniej zauważam, że problemy, które poruszam, dotyczą także (a może przede wszystkim) pedagogiki w innych krajach, zwłaszcza krajach tzw. Zachodu.

Wypowiedź rozpoczynam od uwag historycznych. Drugą część poświęcam uzasadnieniu głównej tezy niniejszego tekstu.

\section{Uwagi historyczne}

Dzieje szeroko pojętego związku etyki z pedagogiką sięgają czasów formowania się teoretycznej refleksji o wychowaniu, a więc okresu starożytności greckiej (Homplewicz 1996). Problem obecności moralności w wychowaniu wyraźnie pojawił się wraz z ukształtowaniem się greckiego modelu wychowania - paidei. Jednym z jego kluczowych aspektów pozostawało formowanie moralności wychowanków, określane kategorią szlachetności - kalokagatii (Kiereś 2009). Co jednak ciekawe, już w starożytności pojawiła się ambiwalencja dotycząca obecności etyki w edukacji, zarysowane bowiem zostały opozycyjne względem siebie stanowiska w interesującym nas przedmiocie. Sformułowano klasyczne, istotne dla edukacji koncepcje etyczne: intelektualizm moralny (Sokrates) oraz eudajmonizm (Arystoteles); niemniej określony został również praktycznie i subiektywistycznie warunkowany model kształcenia (sofiści), zmierzający do uformowania zespołu technicznych umiejętności, pozwalających sprawnie funkcjonować w ramach zastanego systemu społecznego (Kot 1996).

Podobną dychotomię dostrzec można w kulturze starożytnego Rzymu. Jej pierwotną cechą charakterystyczną pozostawał praktyczny aspekt edukacji zorientowanej na cele państwowe i militarne. Dopiero percepcja kultury greckiej pozwoliła na ukształtowanie się rzymskiej idei humanitas, stanowiącej odpowiednik greckiej paidei (Kot 1996; Nowak 2012; Kiereś 2009).

Problematykę moralnych podstaw (aspektów) edukacji zdecydowanie promowało chrześcijaństwo. Wprowadzając religijną motywację w proces wychowania, warunkowało (przynajmniej aspektowo) osiągnięcie zbawienia poprawnym moralnie postępowaniem. Szereg modeli wychowawczych, opracowanych na terenie krajów chrześcijańskiej Europy, uwypuklało aspekt moralny (por. de Tchorzewski 2013). Odwołanie do moralności stanowiło charakterystyczny element chrześcijańskich koncepcji edukacyjnych. Mimo różnic w rozwiązywaniu kwestii 
dogmatycznych elementem wspólnym dla inspirowanych chrześcijaństwem stanowisk w pedagogice pozostawało m.in. przekonanie o istotności funkcjonowania moralnego człowieka (Kot 1996).

Powyższe przekonanie pojawiało się nie tylko na poziomie praktyki edukacyjnej (pedagogii). Zachowane ono zostało także na poziomie teorii pedagogicznej. Za znamienne uznać trzeba, iż w ramach pierwszego naukowego modelu pedagogiki za jedną $z$ jej fundamentalnych nauk pomocniczych Jan Fryderyk Herbart uznał etykę. W myśl wspomnianego modelu funkcjonowanie pedagogiki jako nauki warunkowane było dorobkiem etyki, filozofii praktycznej (Stępkowski 2008).

Kontynuację poglądów o istotnej zależności między pedagogiką a etyką stanowią personalistyczne koncepcje w edukacji, zwłaszcza odwołujące się do tomizmu. Etyka (aretologia) traktowana jest na w nich jako nieodzowny element pedagogiki (Woroniecki 1995; Kiereś 2009). Uznawana jest ona za jedno z podstawowych źródeł dla teleologicznych i normatywnych treści (poziomu) w pedagogice, podstawę uzasadniającą cele i zasady wychowania (Kunowski 2001; Homplewicz 1996).

Wydaje się, iż radykalna zmiana w sposobie interpretowania potrzeby systemowej obecności etyki w pedagogice warunkowana była rozwojem nowożytnej koncepcji nauki. Przekonanie o ograniczonym znaczeniu poznawczym wartościowania w nauce, sformułowane przez Dawida Hume’a, a wyrażane w sposób dobitny przez pozytywistów (Bronk 2005), zaowocowało stopniowym rugowaniem podejścia normatywnego z nauki. Pozytywistyczny model nauki, stawiający za wzór naukowości nauki przyrodnicze (naturalizm, fizykalizm), znalazł swoją kontynuację również na terenie humanistyki, w tym w pedagogice (Dziaczkowska 2014). Mimo próby obrony metodologicznej specyfiki nauk humanistycznych, podjętej przez Wilhelma Diltheya, Wilhelma Windelbanda, Heinricha Rickerta, Maxa Webera, w ramach której za wyróżnik tej grupy nauk uznawano m.in. ich wartościujący charakter, utrwalenie się pozytywistycznego modelu nauki uprawomocniło niechęć wobec włączania treści wartościujących w strukturę nauki (Kamiński 1992; Nowak 2006).

Innym, znaczącym w tym aspekcie zjawiskiem, są współczesne zmiany społeczno-kulturowe (Grzybek 2007) wraz z dominującym w ich zakresie postmodernizmem (Dziaczkowska 2014; Jaworska-Wikowska 2007). W imię naczelnych zasad: antyuniwersalizmu, antyfundamentalizmu, postawy antyfilozoficznej i antymetafizycznej, antydemarkacjonizmu, antyracjonalizmu postmodernizm wprowadził zdecydowaną krytykę jakichkolwiek powszechnie obowiązujących zasad, także moralnych. Promując zaufanie wobec subiektywnych ocen, upowszechnił się wówczas pogląd o niemożności tworzenia katalogu obiektywnych reguł moralnych oraz o braku możliwości ich racjonalnego uzasadniania (czyli o niemożliwości istnienia etyki). Wydaje się, że w ten sposób postmodernizm przyczynił się do upowszechnienia niechęci wobec etyki oraz jej zastosowania w różnych aspektach współczesnego życia człowieka (Bronk 1998). 


\section{Teza i jej uzasadnienie}

Osiowa teza niniejszego tekstu wyraża przekonanie o konieczności systemowej obecności etyki w pedagogice. Obecność ta jest o tyle istotna, że wyraźnie wprowadza (stanowi jeden z istotnych przypadków) normatywność w strukturę wiedzy pedagogicznej. Powyższe przekonanie traktuję jako konkluzję, podsumowanie diagnozy stanu współczesnej kultury i nauki, w tym stanu pedagogiki. Uzasadnienie głównego dla tekstu twierdzenia bazuje w pierwszym rzędzie na opisach współczesnej mentalności. Podstawowym jej elementem jest pogląd o neutralności, możliwości istnienia niezaangażowanych aksjologicznie (w tym etycznie!) aspektów życia człowieka. Pogląd ten wydaje się przybierać nie tylko formę przypuszczenia. Funkcjonuje on także, a może przede wszystkim, w formie nakazu, reguły określającej ramy życia społecznego. Wydaje się, że wchodzi on w zakres tzw. „Zasady politycznej poprawności”, traktującej oceny i ocenianie jako czynności niepożądane, niedopuszczalne, jako przejaw kultury dominacji i patriarchalizmu (Witkowski 2007). Egalitaryzm, demokracja, subiektywizm, pluralizm, jako preferowane współcześnie wartości, wydają się stać w jawnej sprzeczności z myśleniem opartym na uniwersalnie uzasadnianych kryteriach służących rozróżnianiu (definiowaniu), ocenie, hierarchizowaniu (Nowak 1999; Kowalczyk 2000).

W tym kontekście problem odrzucania (unikania) wartościowania, zwłaszcza wartościowania moralnego, postrzegam jako istotne zagrożenie nie tylko dla religii, religijnie uzasadnianego ładu społecznego czy religijnie warunkowanej pedagogiki. Wydaje się, że dotyczy on cywilizacji zachodniej en block, a jego negatywne skutki uwidoczniają się w różnych aspektach, począwszy do medyczny i techniki ${ }^{2}$, na humanistyce kończąc.

W odniesieniu do humanistyki za typowe zjawiska, stanowiące konsekwencje odejścia od etycznych, i szerzej normatywnych (filozoficznych) podstaw, uznać można technicyzację, komercjalizację czy biurokratyzację tej dziedziny nauki i kultury. Jako przykłady przytoczyć można regulacje określające funkcjonowanie

${ }^{2}$ „[...] największa groźba współczesnej biotechnologii wynika z faktu, iż może ona zmienić naturę ludzką i w związku z tym przenieść nas w «poczłowieczy» etap historii. Przedstawione zostaną argumenty za tym, że jest to rzeczywiście groźba, ponieważ istnieje coś takiego jak natura ludzka i jest to pojęcie znaczące, tej naturze zresztą zawdzięczamy jako gatunek ciągłość naszego istnienia. Wspólnie z religią definiuje ona nasze podstawowe wartości. Natura ludzka kształtuje i ogranicza wszelkie rodzaje ustrojów politycznych, tak więc technika zdolna nas zmienić może mieć złowrogie konsekwencje zarówno dla demokracji liberalnej, jak i dla samej istoty polityki. Może się zdarzyć [...], iż wszelkie konsekwencje biotechnologii są zaskakująco pozytywne i nie mieliśmy racji, niepokojąc się z ich powodu. Może się okazać, że techniki związane z tą dziedziną nauki będą dużo mniej potężne, niż nam się dziś wydaje, lub też ludzie będą używać ich ostrożnie i umiarkowanie. Mam jednak powód, by nie być zbytnim optymistą: biotechnologia, w przeciwieństwie do wielu innych osiągnięć nauki, łączy w nierozerwalną całość oczywiste korzyści z mniej oczywistymi zagrożeniami” (Fukuyama 2004, s. 20). 
administracyjnych ram nauki, niekiedy stojące w sprzeczności ze „zdrowym rozsądkiem", jak chociażby nadmierna parametryzacja osiągnięć i badań naukowych, konieczność planowania oraz określania ich przyszłego, poznawczego i praktycznego wykorzystania (Węgrzyn 2016), wymóg samofinansowania się instytucji naukowych (Lekka-Kowalik 2015).

Zmiany kontekstu funkcjonowania nauki nie pozostają oczywiście bez skutków dla samej nauki czy sposobu jej uprawiania. Odchodzenie od wartościowania w humanistyce powoduje szereg zmian w zakresie jej struktury, np. w aspekcie celów, języka czy metod badawczych. Bodaj podstawowymi są zmiany dotyczące celów badań naukowych ${ }^{3}$. Jak wiadomo, naukom humanistycznym, zwłaszcza pedagogice, przypisuje się dwojakiego rodzaju cele: poznawcze i praktyczne. Oba uznawane były dotychczas za charakterystyczne dla tej grupy nauk, w przeciwieństwie do nauk przyrodniczych, których zasadniczym celem pozostaje cel poznawczy, czyli opis i wyjaśnienie zjawisk (Bronk 2003). Praktyka uprawiania wielu nauk humanistycznych pokazuje jednak, iż także w humanistyce wyraźnie unika się realizacji celów praktycznych, tj. oceny badanych zjawisk i postulowania ich pożądanego stanu bądź przebiegu. Wyrazem tych tendencji jest niewątpliwie behawioryzm w psychologii (Kozielecki 1996), a w odniesieniu do pedagogiki upowszechnienie się jej modelu typowego dla anglosaskiego kręgu kultury, który w miejsce wartościowania (moralnego) wprowadza kryteria funkcjonalności lub koherencji (Nowak 1999).

Oczywiście, uznanie praktycznych celów pedagogiki (humanistyki) nie rozwiązuje problemu ich uzasadnienia. Pytania, na mocy czego oceny i postulaty te są formułowane, co uzasadnia kryteria stosowanych ocen, wydają się w tym aspekcie fundamentalne. Trudności z udzieleniem przekonujących odpowiedzi nie są jednak wystarczającym argumentem dla odrzucenia normatywności pedagogiki. Zabieg taki prowadzi bowiem do negacji podstawowego elementu wyróżniającego pedagogiką spośród innych nauk badających (aspektowo) wychowanie oraz posiada istotne konsekwencje dla praktyki wychowawczej ${ }^{4}$. Wspomniany wyżej

3 „Do etyki (normatywnej) odwołuje się pedagog wówczas, kiedy chce uprawomocnić swe oceny i normy, ustalić ich hierarchię oraz - w przypadku konfliktu wartości preferowanych przez różne koncepcje wychowania - opowiedzieć się po [stronie] jeden z koncepcji” (Brok 2005, s. 23-24).

4 „Rezygnacja ta [z normatywności pedagogiki - przypis autora] stawia jednak pod znakiem zapytania nie tyle i nie tylko status naukowy pedagogiki [...]. Rezygnacja $z$ tych poszukiwań w pedagogice znosi jednak dodatkowo szczególne - «ludzkie» - uzasadnienie racji jej bytu. Tym uzasadnieniem jest realizacja zadania ukazania możliwości wychowania liczącego się z dobrem i godnością każdego człowieka, wychowania mającego na uwadze poszanowanie jego praw. Pedagogika, przestając pytać o to, jak realizować wychowanie w odniesieniu do dobra jego uczestników, gubi troskę o ludzką osobę, nadaje sobie rangę dyscypliny prowadzącej jałowy dyskurs akademicki. Oczywiście, nie można tu zapomnieć o tym, jak trudno wskazać, bez cienia wątpliwości, co jest tym dobrem uczestnika wychowania, ale zaniechanie naukowej dyskusji na ten temat albo - co gorsza - zdanie się w niej na argumentację silnych medialnie 
anglosaski model pedagogiki wyraźnie uświadamia, że pedagogika przestaje być jedną, spójną teoretycznie i metodologicznie dyscypliną, a staje się kompleksem luźno złączonych nauk o wychowaniu (edukacji). Bodaj jedynym elementem wskazującym na ich bliskość (pokrewieństwo) pozostaje przedmiot badań. Natomiast podejścia badawcze, ich zaplecze pojęciowe i metodologiczne, mogą pozostawać zupełnie różne (Bronk 2003).

Przedwojenna pedagogika polska wyraźnie akcentowała spójność wiedzy o wychowaniu, upatrując jej podstawę w normatywności. Klasyczne, polskie koncepcje pedagogiki wskazują na to, iż podstawą odróżniania pedagogiki od innych dyscyplin humanistycznych są jej normatywność i postulatywność. Te cechy dotyczą szczególnie przedmiotu formalnego pedagogiki. Wychowanie rozpatrywane w aspekcie pożądanych (!) form przebiegu i oczekiwanych efektów ${ }^{5}$ uznawane było za element specyfikujący pedagogikę (Woroniecki 1995; Nowak 1999; Kabzińska 2007).

Innym aspektem wyraźnie podlegającym (nie)obecności etyki (a także aksjologii i antropologii) w pedagogice jest język. Wydaje się, że zmiany współczesnego języka pedagogiki, warunkowane różnymi procesami (specjalizacją, precyzacją, popularnością określonych paradygmatów i koncepcji nauki), podlegają także zależnościom pozanaukowym, jak np. upowszechnianie się języka angielskiego i kultury anglosaskiej, a w jej ramach „anglosaskiego”, opisowo-wyjaśniającego modelu pedagogiki. Unikanie terminów mających wyraźne konotacje wartościujące (Homplewicz 1996) wydaje się specyficzne dla współczesnego języka pedagogiki. Wprowadzanie terminów neutralnych etycznie (aksjologicznie) oraz powszechnie dziś używanych nazw o proweniencji administracyjno-ekonomicznej uznać można za przykłady dehumanizacji pedagogiki (humanistyki) ${ }^{6}$. Zmiana języka

grup interesów pozbawia wiarygodnego wsparcia zarówno wychowawców, jak i wychowanków" (Dziaczkowska 2014, s. 44-45).

5 „Pedagogika, zajmująca się wszechstronnym rozwojem ludzi, stara się proces rozwojowy doprowadzić do jego kresu, jakim jest doskonały stan człowieczeństwa. Ta pełnia człowieczeństwa staje się więc praktycznym celem do osiągnięcia przez wychowanie, a równocześnie normą oceniającą, czy proces wychowania przebiega właściwie, czy też odbiega od celu. Dlatego też przedmiotem formalnym w pedagogice musi być dobro rozwojowe człowieka nie aktualnie pojęte, lecz realizujące się w przyszłości, nastawione ku przyszłości, dzięki czemu człowiek może się w pełni doskonalić i osiągnąć kres procesu rozwoju” (Kunowski 2001, s. 39); „[Wychowanie jest to] pomoc, której starsi udzielają stale i według określonego planu młodzieży, aby przez harmonijne rozwinięcie wszystkich jej zdolności wyrobić ją stopniowo na ludzi dobrych, którzy i sami byliby szczęśliwymi, i mogli spełniać wszystkie obowiązki względem Boga i bliźniego” (Podoleński 1921, s. 8); „Wychowanie musi dążyć zatem do tego, aby uczynić młodzież zdolną do przeżywania zasad etosu w całej pełni, a więc zarówno od ich strony rozumowej, jak uczuciowej i woluntalnej [...]. Związane z tem pojęcie powinności i wartości, oraz stosunek etosu do kultury, stanowią zasadnicze podstawy dla wychowania w etosie” (Sośnicki 1933, s. 91).

6 Za typowe „niehumanistyczne” określenia funkcjonujące w pedagogice uznać można przykładowo: „Zasoby ludzkie”, „kapitał ludzki”, „administrowanie zasobami ludzkimi”, „zarządzanie 
nie jest jednak zabiegiem czysto technicznym. Towarzyszy jej niejednokrotnie zmiana teoretyczna, paradygmatyczna. Nie można zapominać bowiem, że terminy, a w zasadzie stojące za nimi pojęcia, warunkowane są określoną teorią, w ramach której powstały (Górniewicz 2001).

Proces wypierania rdzennych terminów i pojęć oraz zastępowania ich terminami obcymi - najczęściej niesionymi przez język angielski - posiada jeszcze jeden, jak sądzę, negatywny aspekt. Chodzi mianowicie o zrywanie z tradycyjnym, rodzimym dorobkiem naukowym. Problem nadmiernego wykorzystywania „światowego" dorobku (w tym adaptacji języka) wydaje się być niejednokrotnie warunkowany swoistą modą, ale także przekonaniem o istotnym znaczeniu odkryć „zagranicznych", przy braku świadomości istnienia rodzimych dokonań lub wprost przy ich niedocenianiu. Sytuacja braku przywiązania do własnego, rodzimego dorobku oraz języka na terenie nauk humanistycznych wydaje się o tyle specyficzna, iż trudno ją porównać $\mathrm{z}$ analogiczną sytuacją na terenie nauk przyrodniczych. O ile tam wymóg uniwersalizacji (unifikacji) i globalizacji wiedzy jest niewątpliwie istotny, o tyle na terenie humanistyki wartościowy wydaje się także pluralizm. O bogactwie wiedzy świadczy wielość i różnorodności jej interpretacji oraz istnienie lokalnych narracji. Oczywiście, postulat spójności terminologicznej nie przestaje obowiązywać. Wymóg komunikacji, a także wymiany doświadczeń dotyczy również humanistów. Niemniej rezygnacja z lokalnej specyfiki i tożsamości stanowi niewątpliwie istotne zubożenie. „Zakładam, że humanistyka definiuje fundamenty naszej tożsamości w wymiarze indywidualnym i wspólnotowym. Humanistyka polska ma zadanie podwójne: $z$ jednej strony odpowiedzieć na wewnętrzne, polskie potrzeby poznawcze, formacyjne, edukacyjne i kulturowe, a z drugiej - uczestniczyć w działaniach na forum szerszym, międzynarodowym, wnosząc wkład do wspólnoty ponadnarodowej, budując obraz Polski w świecie i utwierdzając naszą tożsamość" (Bartmiński 2013, s. 2; por. także: Prokop 2013).

I wreszcie ostatnim z sygnalizowanych aspektów (nie)obecności etyki w pedagogice są zagadnienia dotyczące strategii (metod) badawczych. Pytanie o obecność etyki w pedagogice wprowadza problem zasadności stosowania wartościującej interpretacji wyników badań. Zapewne rozumowanie etyczne trudno uznać za jedyny typ, wyłączne teoretyczne źródło określające sposób analizowania badań pedagogicznych. Niemniej trudno zaprzeczyć, że pedagogiczne interpretacje uzyskanych w trakcie badań wyników (Ostrowska 2007) wyraźnie odwołują się do etycznych kryteriów, zarówno wprost, jak i w formie założeń przyjmowanych implicite ${ }^{7}$.

karierą”, „jakość życia”, „pomiar osiągnięć ucznia”, „rynek edukacyjny”.

7 Sądzę, że przykładem odwołania wprost do etyki w badaniach empirycznych w pedagogice jest użycie kategorii: „demoralizacja”, „godność człowieka”, „dobro”, „dobro rozwojowe wychowanka” (Wach 2014), „charakter” (Lendzion 2012), „dojrzałość moralna” lub „dobro dziecka” (Magier 2013), „kompetencja moralna” (Nowak 2006). 
Mimo że czasy „twardego” empiryzmu, uznającego zasadność stosowania jedynie strategii (metod) ilościowych w pedagogice, przeminęły, sytuacja dotycząca relacji między ilościowym a jakościowym paradygmatem badań nie jest jasna. Postulat łączenia obu podejść wydaje się być niejednokrotnie wypowiadany w sposób naiwny, pomijający istotne problemy tej fuzji. Praktyka badawcza i dydaktyczna pokazuje, iż badania jakościowe i metaprzedmiotowe, zawierające aspekt wartościowania, ciągle traktowane są jak badania „gorszego typu”. Za rzetelną wiedzę uznaje się jedynie tę uzasadnioną opracowanymi statystycznie wynikami. „Fakt uznania różnorodności dróg postępowania badawczego w publikacjach z zakresu metodologii badań pedagogicznych nie zawsze koreluje z krytycznym uznaniem tejże różnorodności w praktyce akademickiej [...]. Potwierdzeniem tego bywają ostre spory na etapie zatwierdzania koncepcji czy obrony rozpraw doktorskich, a także przy okazji oceniania i recenzowania prac magisterskich i licencjackich. W sporach tych wybrzmiewa niekiedy niezrozumienie specyfiki jakościowego warsztatu pracy badawczej w pedagogice. Za «badania» niektórzy pedagodzy wciąż uważają jedynie poszukiwania empiryczne" (Dziaczkowska 2014, s. 34-35).

W konsekwencji zarysowany spór sięga istoty: kryteriów oraz zasadności nagminnie stosowanego podziału na metody (strategie) ilościowe i jakościowe badań. Wydaje się, że w przeciwieństwie do propozycji Stefana Kunowskiego ${ }^{8}$ analizowany podział eksponuje kryterium celu (sposobu interpretacji wyników). Jeśli uznamy, że w podejściu ilościowym celami są opis i wyjaśnienie, to dla strategii jakościowej za cele uznać można rozumienie (w aspekcie historycznym, psychicznym) zjawisk oraz ich ocenę. Istotne w tym względzie wydaje się uzasadnienie zabiegu wprowadzania interpretacji jakościowych w strukturę badań ilościowych lub wykluczanie ich ze strategii ilościowej (!). Chodzi zwłaszcza o aspekt wartościowania, jak zasygnalizowałem wyżej, typowy dla pedagogiki, niemniej pozostający poza modelem (paradygmatem) badań ilościowych (Urbaniak-Zając, Kos 2013; Rubacha 2008).

\section{Zakończenie}

Oczywistą rzeczą jest, że ton współczesnej nauce nadaje przyrodoznawstwo. To ono generuje najbardziej spektakularne odkrycia naukowe oraz technologiczne. Procedury badawcze wypracowane na terenie nauk przyrodniczych uznawane są ciągle za wzór naukowości. Ich prestiż poznawczy koresponduje również z wysokim ekonomiczno-kulturowym statusem przyrodoznawstwa, zwłaszcza w krajach zachodniej Europy oraz USA.

Niewątpliwie w cieniu nauk przyrodniczych pozostaje humanistyka, postrzegana jako dział nauki o niższym statusie poznawczym i metodologicznym. Pomijanie

${ }^{8}$ Przypomnijmy, że S. Kunowski za uzasadnienie wyboru określonej metody badań uznaje specyfikę badanego przedmiotu oraz macierzysty dla danej metody typ nauki: przyrodniczej lub humanistycznej (Kunowski 2001). 
bogatego dorobku humanistyki, w tym jej polskich osiągnięć, wydaje się jednak niebezpieczne. Chodzi nie tylko o aspekt poznawczy, lecz także o fakt pełnienia przez nauki humanistyczne istotnych funkcji społecznych: określania tożsamości, rdzenia (rodzimej) kultury (Lekka-Kowalik 2015).

Próba uzasadnienia potrzeby obecności etyki w pedagogice prowadzi do przekonania o konieczności systemowej współpracy pedagogiki z wieloma dyscyplinami filozofii. Związek pedagogiki z etyką traktować można jako przykład uzasadniający konieczność wykorzystania normatywnych dyscyplin wiedzy w badaniach pedagogicznych. Sądzę także, iż przedmiotowa relacja jest konstytutywna dla pedagogiki, zwłaszcza w aspekcie jej dyscyplinarnej tożsamości.

Uznać można, że wykorzystanie dorobku etyki w pedagogice stanowi swoisty gwarant jej humanistycznego charakteru. Zrozumiała wydaje się troska pedagogów o naukowy status dyscypliny, którą uprawiają. Pewien żal towarzyszy jednak konstatacji, iż nierzadko troska ta przyjmuje postać znaczącego podporządkowania pedagogiki naturalistycznemu paradygmatowi nauki, prowadzącego do radykalnych zmian tej dyscypliny (Nowak 1999), a niekiedy do utraty jej specyfiki i tożsamości (Woroniecki 1995).

\section{Bibliografia}

Bartmiński J. (2013). Głos w dyskusji o polskiej humanistyce. „PAUza Akademicka”, nr 223, s. 2.

Bronk A. (1998). Zrozumieć świat współczesny. Lublin: Towarzystwo Naukowe Katolickiego Uniwersytetu Lubelskiego.

Bronk A. (2003). Czy pedagogika jest nauką autonomiczna? W: M. Nowak, T. Ożóg, A. Rynio (red.). W trosce o integralne wychowanie. Lublin: Wydawnictwo KUL, s. $47-76$.

Bronk A. (2005). Pedagogika i filozofia: uwagi metafilozoficzne. W: P. Dehnel, P. Gutowski (red.). Filozofia a pedagogika. Szkice i studia. Wrocław: Wydawnictwo Naukowe Dolnośląskiej Szkoły Wyższej Edukacji TWP we Wrocławiu, s. 9-27.

Dziaczkowska L. (2014). Akademickie problemy z metodologia pedagogiki. „Roczniki Pedagogiczne", nr 6 (42), z. 1, s. 33-51.

Fukuyama F. (2004). Koniec człowieka. Konsekwencje rewolucji biotechnologicznej, tłum. B. Pietrzyk. Kraków: Wydawnictwo Znak.

Górniewicz J. (2001). Kategorie pedagogiczne. Olsztyn: Wydawnictwo Uniwersytetu Warmińsko-Mazurskiego.

Grzybek G. (2007). Etyka, rozwój, wychowanie. Bielsko-Biała: Wydawnictwo Akademii Techniczno-Humanistycznej w Bielsku-Białej.

Homplewicz J. (1996). Etyka pedagogiczna. Warszawa: Wydawnictwo Salezjańskie. Jaworska-Witkowska M. (2007). Między przemoca a niemocą: etyka pedagogiczna a estetyki rytualizacji ofiary w edukacji. W: W. Sawczuk (red.). Po co etyka pedagogom? Toruń: Wydawnictwo Adam Marszałek, s. 91-112. 
Kabzińska Ł. (2007). Koncepcje etyczne nauczyciela $w$ myśli pedentologicznej okresu międzywojennego. W: W. Sawczuk (red.). Po co etyka pedagogom? Toruń: Wydawnictwo Adam Marszałek, s. 234-250.

Kamiński S. (1992). Nauka i metoda. Pojęcie nauki i klasyfikacja nauk. Lublin: Towarzystwo Naukowe Katolickiego Uniwersytetu Lubelskiego.

Kiereś B. (2009). O personalizm w pedagogice. Lublin: Fundacja Servire Veritati Instytut Edukacji Narodowej.

Kot S. (1996). Historia wychowania. T. 1. Warszawa: Wydawnictwo „Żak”.

Kozielecki J. (1996). Koncepcje psychologiczne człowieka. Warszawa: Wydawnictwo „Żak”.

Kowalczyk S. (2000). Wolność naturą i prawem człowieka. Sandomierz: Wydawnictwo Diecezjalne.

Kunowski S. (2001). Podstawy współczesnej pedagogiki. Warszawa: Wydawnictwo Salezjańskie.

Lekka-Kowalik A. (2015). Dlaczego uniwersytet nie może i nie powinien być biznesem. „Przegląd Uniwersytecki”, nr 6 (158), s. 10-12.

Lendzion A. (2012). Młodzież a wartości charakterologiczne. Lublin: Wydawnictwo KUL.

Łuczyński A. (2008). Dzieci w rodzinach zastępczych i dysfunkcjonalnych. Lublin: Wydawnictwo KUL.

Magier P. (2013). O pedagogicznym rozumieniu „dobra dziecka”. W: J. Daszykowska, A. Łuczyński (red.). Dziecko w przestrzeni życia społecznego. Stalowa Wola: Wydział Zamiejscowy Nauk o Społeczeństwie Katolickiego Uniwersytetu Lubelskiego Jana Pawła II w Stalowej Woli, s. 27-50.

Majdański S. (2009). O autorytecie i idei uniwersytetu. „Summarium”, R. 38 (58), s. $63-80$.

Michalik-Surówka J. (2003). Etyka dyskursu. W: T. Pilch (red.). Encyklopedia Pedagogiczna XXI Wieku. Warszawa: Wydawnictwo Akademickie „Żak”, s. $1069-1070$.

Nowak M. (1999). Podstawy pedagogiki otwartej. Lublin: Redakcja Wydawnictw Katolickiego Uniwersytetu Lubelskiego.

Nowak M. (2012). Pedagogiczny profil nauk o wychowaniu. Studium z odniesieniami do pedagogiki pielegniarstwa. Lublin: Wydawnictwo KUL.

Nowak Z. (2006). Kompetencje moralne jako kategoria teoretyczna i badawcza w pedagogice wczesnoszkolnej. Kraków: Wydawnictwo Naukowe Akademii Pedagogicznej.

Ostrowska U. (2007). Etyczne aspekty procesu badawczego (ze szczególnym uwzględnieniem pedagogicznych badań jakościowych). W: W. Sawczuk (red.). Po co etyka pedagogom? Toruń: Wydawnictwo Adam Marszałek, s. 55-69.

Podoleński S. (1921). Podręcznik pedagogiczny. Kraków: Nakładem Wydawnictwa Ks. Jezuitów, Kopernika 26.

Prokop J. (2013). Debata nad polska humanistyką. „PAUza Akademicka”, nr 223, s. 4. 
Rubacha K. (2008). Metody zbierania danych $w$ badaniach pedagogicznych. W: Z. Kwieciński, B. Śliwerski (red.). Pedagogika. Podręcznik akademicki, t. 1. Warszawa: Wydawnictwo Naukowe PWN, s. 34-58.

Sośnicki K. (1933). Podstawy wychowania państwowego. Lwów - Warszawa: Książnica Atlas.

Stępkowski D. (2008). Miedzy pedagogika a filozofia Herbarta. „Roczniki Nauk Społecznych. Zeszyt 2 - Pedagogika", t. 36, s. 75-97.

Szczęsny W. W. (2003). Etyka. W: T. Pilch (red.). Encyklopedia Pedagogiczna XXI Wieku. Warszawa: Wydawnictwo Akademickie „Żak”, s. 1067-1068.

Szewczak I. (2013). Dziecko i dzieciństwo w wymiarze moralnym. W: J. Daszykowska, A. Łuczyński (red.). Dziecko w przestrzeni życia społecznego. Stalowa Wola: Wydział Zamiejscowy Nauk o Społeczeństwie Katolickiego Uniwersytetu Lubelskiego Jana Pawła II w Stalowej Woli, s. 51-70.

Tchorzewski de A.M. (2013). Sprawności moralne jako wyraz świadomości wychowawczej i kultury pedagogicznej. W: I. Jazukiewcz, E. Rojewska (red.). Sprawności moralne wychowawcy. Szczecin: Uniwersytet Szczeciński, Przedsiębiorstwo Produkcyjno-Handlowe ZAPOL Dmochowski, Sobczyk, s. 11-28.

Urbaniak-Zając D., Kos E. (2013). Badania jakościowe w pedagogice. Warszawa: Wydawnictwo Naukowe PWN.

Wach T. (2014). Charakter adolescencyjnych zachowań trudnych a inicjowanie oddziaływań wychowawczo-resocjalizujacych. „Roczniki Pedagogiczne”, T. 6(42) nr 4, s. 85-101.

Węgrzyn G. (2016). Jasnowidz i wskaźniki projektu naukowego. „PAUza Akademicka”, nr 323, s. 2-3.

Witkowski L. (2007). O nowych polach i wymiarach odpowiedzialności etycznej w pedagogice. W: W. Sawczuk (red.). Po co etyka pedagogom? Toruń: Wydawnictwo Adam Marszałek, s. 26-43.

Woroniecki J. (1995). Katolicka etyka wychowawcza, t. 1 : Etyka ogólna. Lublin: Redakcja Wydawnictw KUL.

\title{
ABOUT THE NEED OF ETHICS IN PEDAGOGY
}

\begin{abstract}
The subject of this article is the relation between pedagogy and ethics. The character of the article is analytical and metatheoretical. The article aims at justifying the thesis about the need of systemic presence of ethics in pedagogy. In the author's opinion, the lack of ethics leads to the degeneration of pedagogy as a field of study in its normative aspect (level). The formulated thesis is regarded by the author as crucial in the context of discussions concerning the scientific status of pedagogy: its humanistic specificity as well as popularisation of the naturalistic paradigm of study in particular.
\end{abstract}

Keywords: ethics, pedagogy, prescriptivism, the Polish tradition of practising pedagogy, aims, language, research methods of pedagogy, naturalism. 
Piotr Magier - doktor nauk społecznych w zakresie pedagogiki, zatrudniony na stanowisku adiunkta w Katedrze Pedagogiki Ogólne Instytutu Pedagogiki Katolickiego Uniwersytetu Lubelskiego Jana Pawła II. Dorobek naukowy obejmuje około 50 artykułów i współredakcję dwóch prac zbiorowych: Antropologiczna pedagogika ogólna (2010) i Przedszkolaki idą do szkoły. Diagnoza gotowości szkolnej dzieci pięcioletnich i sześcioletnich radomskich przedszkoli (2012). Adres mejlowy: piotr.magier@kul.lublin.pl. 